\title{
Petrology and geochronology of felsic volcanics in the Sabga area (Bamenda Highlands): implications for age variation along the Cameroon Volcanic Line
}

\author{
Edith Etakah BATE TIBANG ${ }^{1,2^{*}}$, Cheo Emmanuel SUH' ${ }^{1,3}$, John COTTLE ${ }^{4}$, Kevin ljunghi \\ ATEH ${ }^{1}$, Anicet Feudjio TIABOU ${ }^{5}$, Linus Anye NCHE${ }^{1}$, Vivian Bih $\mathrm{CHE}^{5}$, Akumbom VISHITI \\ ${ }^{1}$ Economic Geology Unit, Department of Geology, University of Buea, P.O. Box 63, Buea, South West Region, Cameroon \\ 2 Institute for Geological and Mining Research (IRGM), P.O. Box 333, Garoua, Cameroon; edithbate@yahoo.com \\ ${ }^{3}$ Department of Geology, Environmental Science \& Mining, Faculty of Science, University of Bamenda, P.O. Box 39 Bambili, North West \\ Region, Cameroon \\ ${ }^{4}$ Department of Earth Sciences and Earth Research Institute, Webb Hall 2028, University of California, Santa Barbara, CA 93106-9630, \\ USA \\ ${ }^{5}$ Remote Sensing Unit, Department of Geology, University of Buea, P.O. Box 63, Buea, South West Region, Cameroon \\ ${ }^{6}$ Department of Civil Engineering, University of Technology, University of Douala, P.O. Box 8698, Littoral Region, Cameroon \\ ${ }^{*}$ Corresponding author
}

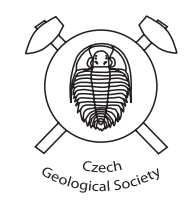

\begin{abstract}
The textural characteristics of felsic lavas and ignimbrites in the Sabga area along the continental segment of the Cameroon Volcanic Line (CVL) are documented in this study. Two rhyolitic lava flows separated by mafic and rhyodacitic lava flows were dated by zircon LA-ICP-MS technique in order to constrain the timescales of successive flow emplacement as well as magma chamber processes in this volcanic field. The studied samples have rheomorphic characteristics such as eutaxitic textures defined by elongated fiamme as well as deformed and welded glass shards. They exhibit flow banding and contain spherulitic groundmass. Rhyolitic autobreccias and ignimbrites are widespread in the Sabga area, are peralkaline in nature and their ages are broadly similar at $\sim 23.0 \pm 0.3 \mathrm{Ma}(23.34 \pm 0.34 \mathrm{Ma}$ for the ignimbrite and $22.98 \pm 0.28 \mathrm{Ma}$ for the rhyolitic autobreccia unit). These ages suggest rapid recharge of magma into a periodically replenished and open chamber. The felsic rocks in the Sabga area and around the Bamenda Highlands are also younger compared to other felsic units along the CVL (29 Ma to $69.4 \pm 0.4 \mathrm{Ma})$.
\end{abstract}

Keywords: Cameroon Volcanic Line, Bamenda Highlands, zircon dating, flow banding, rhyolitic ignimbrite, rhyolitic autobreccia Received: 19 July, 2017; accepted: 27 December, 2017; handling editor: V. Rapprich

\section{Introduction}

Silicic volcanism is usually explosive producing falls and large-volume pyroclastic flow deposits generally associated with caldera-forming events (Milner et al. 2003; Singer et al. 2014). Silicic volcanic rocks including extensive lavas and lava-like ignimbrites have been recognized to be abundant in the geologic record (Henry and Wolf 1992). Large silicic magma systems host some of the most hazardous volcanoes on Earth (Self 2006; Barker et al. 2014) such as the Bishop Tuff in California (Wilson and Hildreth 1997) and the Taupo Volcano, New Zealand (Houghton et al. 1995).

Evaluating the dynamic evolution of silicic magma systems depends critically on knowing the timescales over which magma-chamber processes (e.g. magma generation, segregation, accumulation, ascent, emplacement, storage, recharge, solidification, residence, crystal fractionation) and eruption occur (Seitz et al. 2016). Magma-chamber processes in these systems before an eruption occur on timescales as short as decades, and the whole magma system can be rebuilt over millions of years (Wilson and Charlier 2016). These timescales of silicic magmatic evolution can be investigated through dating and study of the sequence of volcanic eruption products. The interpretation of magma-chamber processes and the time scales at which they occur are effectively achieved through single crystal dating of zircons by $\mathrm{U}-\mathrm{Pb}$ technique (e.g. Miller and Wooden 2004; Klemetti and Clynne 2014; Barker et al. 2014). The results are relevant in hazard assessment at active silicic volcanoes as they allow for a better comprehension of magma plumbing systems.

Prominent among the numerous large volcanic provinces in the World is the intraplate chain of volcanoes in West Africa known as the Cameroon Volcanic Line (CVL; Fig. 1; Okereke 1988; Marzoli et al. 1999; Njome and de Wit 2014). The CVL comprises several eruption centers separated by uplifted and eroded older plutonic complexes. The volcanic history, tectonic evolution and source of carbon dioxide enrichment in volcanic lakes along the CVL remain debated (see summary in 

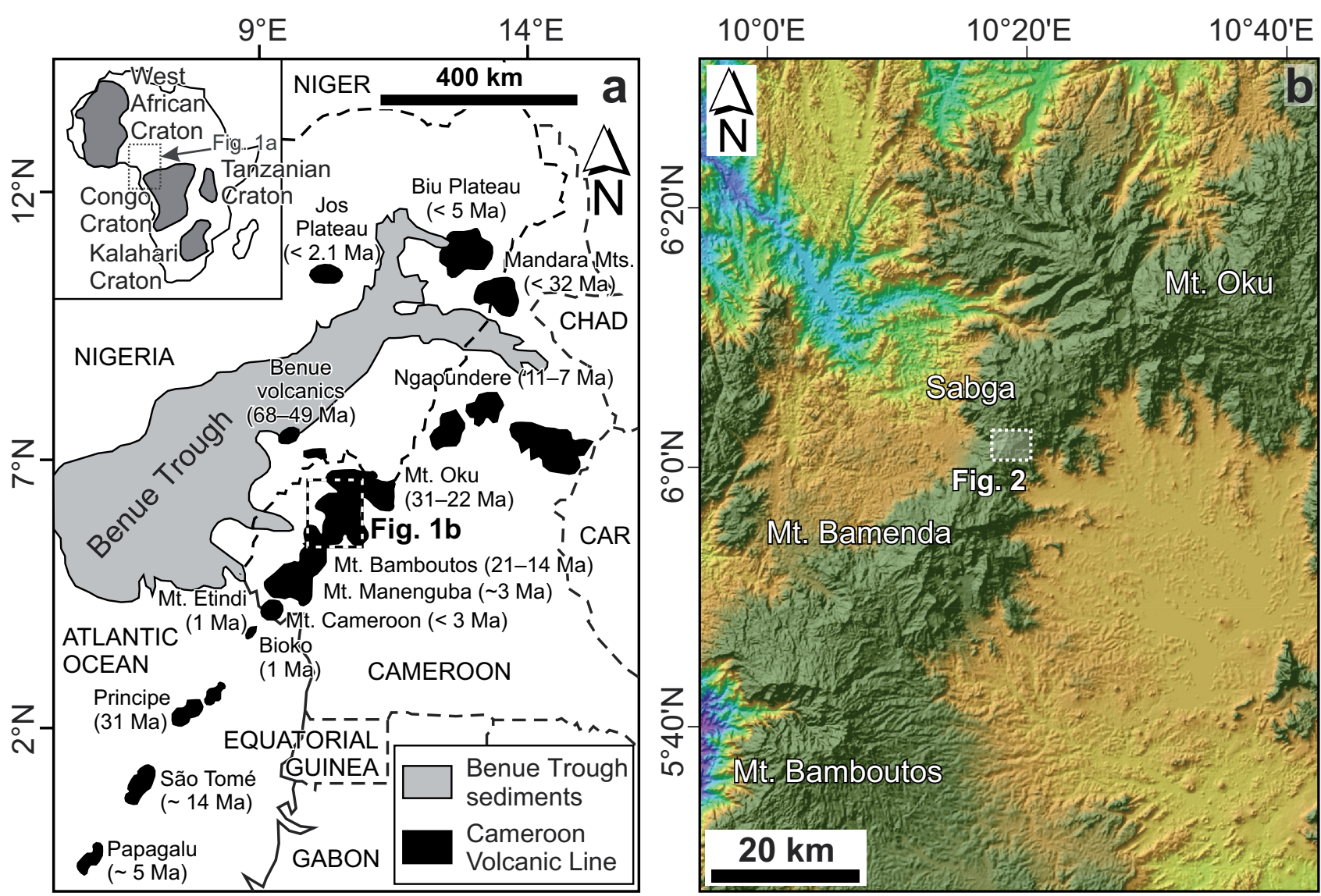

Fig. 1 Location of the Sabga area within the Cameroon Volcanic Line (CVL): a - Main volcanic systems of the Cameroon Volcanic Line; b - Study area within the Mt. Bamboutos - Mt. Oku zone of the CVL.

Njome and de Wit 2014). Lavas along the CVL are both mafic and felsic. The mafic ones concentrate especially around Mt. Cameroon (Fig. 1), where they have been studied in most detail (e.g. Njome et al. 2008; Suh et al. 2008; Wantim et al. 2013). Felsic lavas in the Sabga area of the central segment of the CVL, known as the Bamenda-Oku axis, have been subject to less systematic stratigraphic scrutiny despite their importance for understanding the history of the CVL system.

The Sabga area forms part of the Bamenda Highlands and hosts voluminous felsic volcanic rocks. These rocks crop out as lava domes, lava flows and pyroclastic flow deposits. Marzoli et al. (1999) reported widespread and relatively thick (up to $300 \mathrm{~m}$ ) volcanic sequences at Sabga Pass (Fig. 1b). Studies in the Bamenda Highlands (e.g. Marzoli et al. 1999, 2000; Kamgang et al. 2007, 2008, 2010, 2013) have focused on the geochemistry, petrogenesis of silicic and mafic rocks, as well as $\mathrm{K}-\mathrm{Ar}$ and $\mathrm{Ar}-\mathrm{Ar}$ feldspar geochronology. Existing ages are of relatively low precision, and there is a need for more precise and systematic dating of rocks in this region based on careful sampling of successive eruptive layers.

Here we present a suite of zircon age determinations from two stratigraphic horizons in the Sabga area to trace age variations in the magmatic system recorded in single zircons. These data combined with the zircon textures enable assessing the overall petrogenetic context and timing of interaction of zircon crystals with magma. These data are compared with other felsic explosive volcanic systems globally.

\section{Geological setting}

The Cameroon Volcanic Line (CVL; Fig. 1a) is a NESW-trending intraplate "fan-shaped" alkaline volcanoplutonic rift zone $\sim 2000 \mathrm{~km}$ long and generally less than $200 \mathrm{~km}$ wide. It extends across the Gulf of Guinea (Pagalu, São Tomé, Principe, and Bioko islands) through Cameroon (Mts. Cameroon, Manengouba, Bambouto, Oku, Adamawa Plateau) to Lake Chad (Njome and de Wit 2014). The crystalline basement of the CVL forms part of the mobile belt between the West Africa and Congo cratons and comprises Pan-African granitoids (Toteu et al. 1994; Van Schmus et al. 2008).

Sabga area belongs to the Bamenda Highlands and is sited at latitudes $6.01^{\circ}$ to $6.04^{\circ} \mathrm{N}$ and longitudes $10.32^{\circ}$ to $10.34^{\circ} \mathrm{E}$ (Fig. 1b). The Bamenda Highlands is the fourth largest volcanic massif along the continen- 
tal segment of the CVL and lies mid-way between Mt. Bambouto to the SW and Mt. Oku to the NE (Kamgang et al. 2010; Fig. 1a). Volcanic activity in this segment started with extrusion of alkaline basalts, and continued with voluminous silicic volcanic rocks, scarce rhyolitic ignimbrites followed by voluminous quartz-normative trachytic lava flows, and rare rhyolitic ignimbrites at the top of the sequence (Marzoli et al. 1999; Fig. 2). These silicic volcanic rocks are closely associated with lowto moderately-alkaline basalts, hawaiites and basanites (Marzoli et al. 1999; Kamgang et al. 2007, 2010, 2013). The rhyolitic ignimbrites consist of welded and nonwelded massive lapilli tuff and lithic breccias (Gountie Dedzo et al. 2011).

According to Kamgang et al. (2007, 2008, 2010), $\mathrm{K}-\mathrm{Ar}$ and $\mathrm{Ar}-\mathrm{Ar}$ ages for felsic rocks range from 12.5 to 27.4 Ma. The ages divided the entire sequence into older rocks with an age-range 18.0-27.4 Ma and younger rocks with an age-range 12.5-13.5 Ma. The lower felsic unit of Sabga area was emplaced at $23.0 \pm 0.04 \mathrm{Ma}$ (Marzoli et al. 1999) and forms part of the older felsic rocks in the Bamenda Highlands.

\section{Analytical methods}

\subsection{Whole-rock analyses}

Half of each of the two samples $(\sim 1 \mathrm{~kg})$ collected was crushed, pulverised to 200 mesh and analyzed for majorand selected trace-elements. The geochemical analysis was performed at Acme Analytical laboratories Ltd., Vancouver, Canada, using a combination of inductively coupled plasma optical emission spectrometry (ICPOES) and mass spectrometry (ICP-MS). Before analysis for major and trace elements, $0.2 \mathrm{~g}$ of sample was fused using lithium metaborate/tetraborate and digested using dilute nitric acid. Loss on ignition was determined by weight difference after ignition at $1000^{\circ} \mathrm{C}$. To ensure data quality (95\% confident level) and to calibrate the equipment for optimal precision, a replicate, standard and blank was measured. Accuracy for the major and trace elements was within $5 \%$ error margin.

\subsection{Geochronology}

The U-Pb laser ablation inductively coupled plasma mass spectrometry (LA-ICP-MS) isotopic data were obtained for two samples of the felsic units. Zircon crystals were obtained from their host rocks at University of California Santa Barbara (UCSB) by standard crushing, gravimetricand magnetic-separation techniques. Individual crystals were handpicked, mounted in epoxy resin and polished halfway through individual crystals.

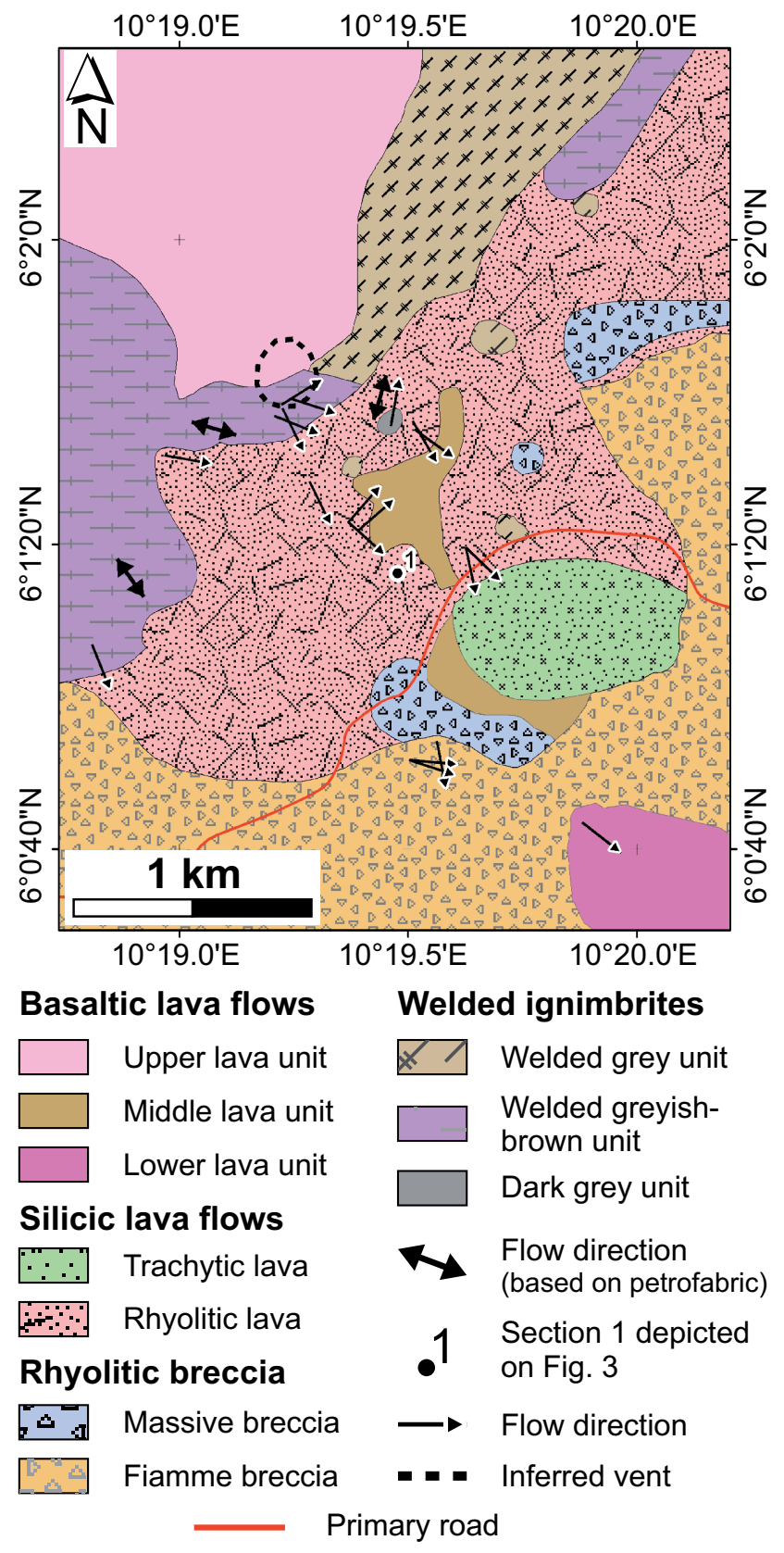

Fig. 2 Geologic map of Sabga area showing the spatial distribution of sections studied and flow directions inferred from field measurements. Number 1 indicates position of the stratigraphic log from which samples dated were collected (Fig. 3).

Cathodoluminescence (CL) imaging was performed to reveal the internal structures of zircons and to identify the potential analytical sites suitable for determining the magmatic crystallization age of crystals. The CL system was attached to a FEI Quanta400f Scanning Electron Microscope housed at the Department of Earth Science, UCSB.

For the $\mathrm{U}-\mathrm{Pb}$ analyses, $\mathrm{U}-\mathrm{Th} / \mathrm{Pb}$ isotope data were collected using a split-stream LA-ICP-MS facility located at UCSB. Methods followed those outlined 
in Kylander-Clark et al. (2013) with modifications as presented in McKinney et al. (2015) and are briefly summarized here.

The cleanest crack- and inclusion-free zircon grains were ablated with a Photon Machines 4-ns pulse duration 193-nm wavelength ArF excimer laser ablation system with a $25 \mu \mathrm{m}$ spot diameter, $4 \mathrm{~Hz}$ frequency, a laser energy of $100 \%$ of $3 \mathrm{~mJ}$ (equating to a fluence of $\sim 1.7 \mathrm{~J} / \mathrm{cm}^{2}$ ) and 100 shots per analysis.

The isotopic ratios were measured using a Nu Plasma HR multi-collector (MC) ICP-MS attached to the laser-

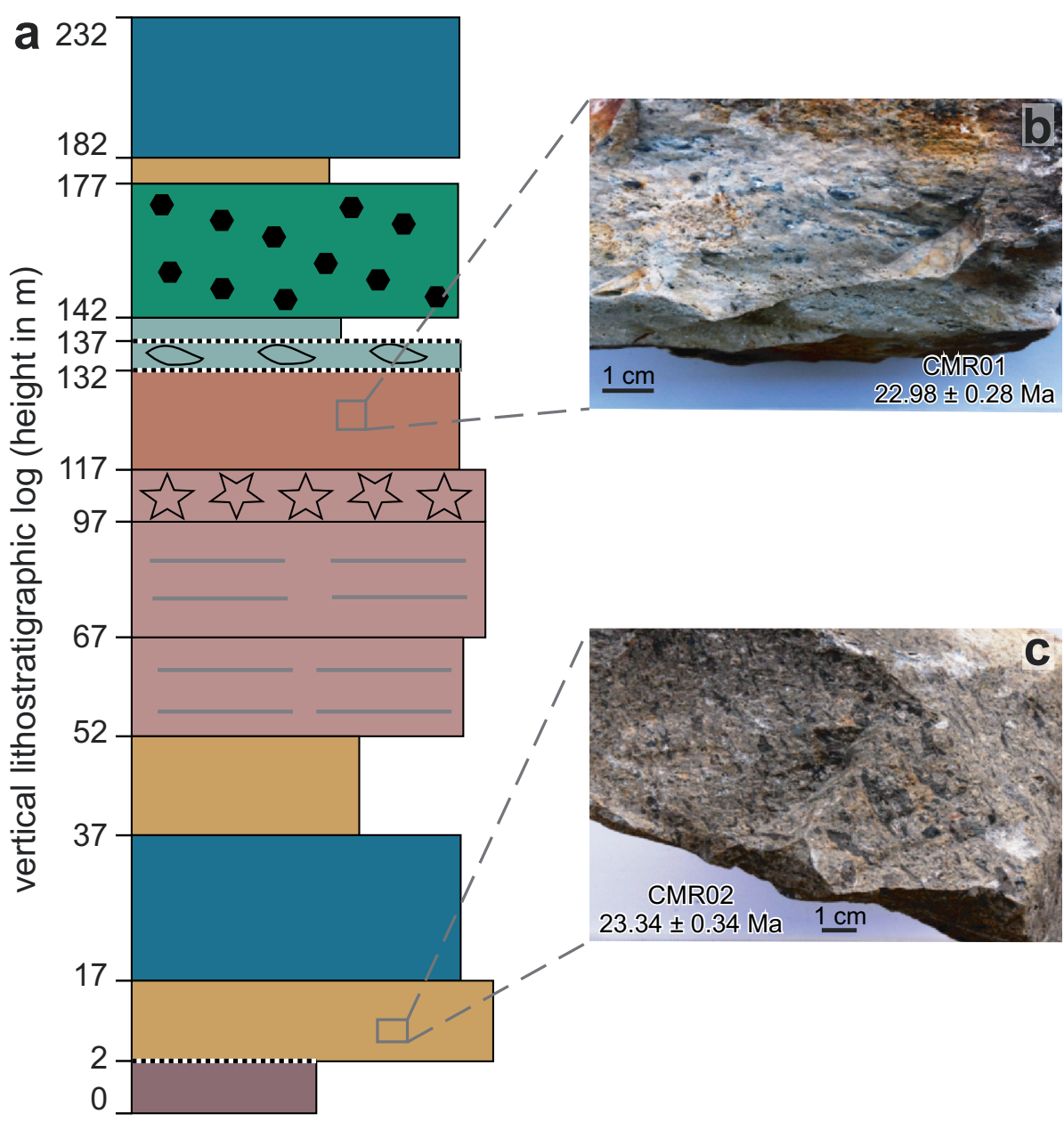

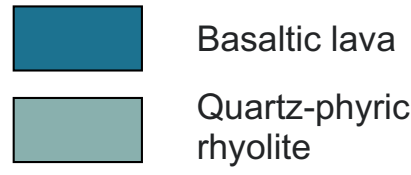
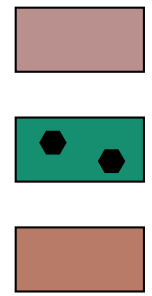

Feldspar-phyric rhyolite

Feldspar-phyric rhyolite with mafic enclaves

Rhyolitic autobreccia ablation system. In order to monitor and correct for instrumental drift, mass bias, and down-hole inter-element fractionation, zircon standard $91500\left[1065 \mathrm{Ma}^{206} \mathrm{~Pb} /{ }^{238} \mathrm{U}\right.$ isotope dilution-thermal ionization mass spectrometry age, Wiedenbeck et al. 1995)] was used as a primary reference material. Secondary reference zircon GJ-1 (601.7 $\pm 1.3 \mathrm{Ma}$, Horstwood et al. 2016) was analyzed concurrently (once every 8 unknowns) to monitor data accuracy, and mass bias- and fractionation-corrected based on measured isotopic ratios of the primary reference material. Same spot size was analysed for the reference material and the dated zircons.

Data reduction for the $\mathrm{U}_{-}$ $\mathrm{Pb}$ isotope analyses was performed using Igor Pro and the plugin Iolite v. 2.5 Data (see Paton et al. 2010 for details on data-reduction methodology). The ${ }^{206} \mathrm{~Pb} / 238 \mathrm{U}$ isotopic ratios were corrected for common $\mathrm{Pb}$ by using the ${ }^{207} \mathrm{~Pb}$ method of Williams (1998); initial common $\mathrm{Pb}$ estimation was according to Stacey and Kramers (1975). All uncertainties including contributions from the reproducibility of the reference materials for ${ }^{207} \mathrm{~Pb} /{ }^{206} \mathrm{~Pb}$, ${ }^{206} \mathrm{~Pb} /{ }^{238} \mathrm{U}$ and ${ }^{207} \mathrm{~Pb} /{ }^{235} \mathrm{U}$ during the analytical sessions (70 GJ1-34 unknowns) are cited at $2 \sigma$ confidence level. Concordia diagrams were plotted using ISOPLOT 3.0 (Ludwig 2003) in which upper and lower intercepts could be interpreted. During the analytical period, repeat analyses of the GJ-1 standard gave a weighted mean ${ }^{206} \mathrm{~Pb} /{ }^{238} \mathrm{U}$ age of $599.0 \pm 0.8$ $\mathrm{Ma}$, mean square of weighted deviates (MSWD) of 0.8 , and a ${ }^{207} \mathrm{~Pb} /{ }^{206} \mathrm{~Pb}$ age of $601 \pm 3 \mathrm{Ma}$ $(\mathrm{n}=70)$.

\section{Basal obsidian}

Stretched vesicles

Brecciated domain

Flow banding

Erosional base
Fig. 3 Vertical lithostratigraphic $\log$ of the studied area (a) with position of sampled rock-specimens marked: rhyolitic autobreccia CMR01 (b) and rhyolitic ignimbrite CMR02 (c). 


\section{Results}

\subsection{Field relations and petrology}

The study area is characterized by an elongated breached crater with long and short axes of $1000 \mathrm{~m}$ and $400 \mathrm{~m}$, respectively (Fig. 2). The volcanic successions occur as alternations of felsic and rare basaltic units. The felsic units in the area are dominantly welded rhyolitic ignimbrites, rhyolitic breccias, trachytic lava flows and rhyolitic lava flows. The facies architecture and stratigraphic reconstruction of the area (results of this study) are illustrated in the composite vertical log in Fig. 3a. This log shows a basaltic layer sandwiched by the two dated felsic layers. The felsic rocks encountered in the area occur as domes, or rounded and jointed elongated blocks with vertical axes in the range of 5-10 m. The lava domes are primary volcanic forms while the rounded blocks resulted from weathering of pre-existing larger volcanic bodies. The felsic rocks have various breccia textures: crackle, mosaic, chaotic, mesocataclasite and protocataclasite and range from coherent lava facies to welded pyroclastic units. The lava sequences were systematically sampled from bottom to top and the samples chosen for dating are separated by mafic lavas and comprise the dominant textural varieties of rhyolitic materials in the lithologic section. The dated samples are a rhyolitic autobreccia and a welded ignimbrite.

The rhyolitic autobreccia (CMR01) is fine-grained mesocataclasite that occurs as boulders. It shows evidence of multiple episodes of auto-brecciation and annealing (clast-in-clast inclusion) and it is characterized by dark wispy flow bands, with stretched minerals and lithic fragments (Fig. 3b). Petrographically, the autobreccia contains oriented vesicles $2-6 \mathrm{~mm}$ diameter filled with chalcedony entombed in a glassy and devitrified groundmass (Fig. 4a).

The dated rhyolitic ignimbrite (CMRO2) is welded, light brown to grey in color and consists of dark fiamme which are aligned, giving rise to a flow-foliation and defining a porphyritic-eutaxitic texture (Fig. 3c). Rare basaltic clasts, resorbed and partly rounded, are also common within the rhyolitic ignimbrites.

The welded ignimbrite is lithic-poor and characterized

Fig. 4 Photomicrographs (plane-polarized light) of studied samples: a - Chalcedony-filled vesicle (amygdale; v) in rhyolitic autobreccia (CMR01); b-Spherulite (s) in rhyolitic ignimbrite (CMR02). Q - Quartz.
Tab. 1 Whole-rock major- (wt \%) and trace-element (ppm) analyses of the two dated rhyolitic rocks

\begin{tabular}{|c|c|c|}
\hline Sample & CMR01 & CMR02 \\
\hline $\mathrm{SiO}_{2}$ & 70.33 & 68.42 \\
\hline $\mathrm{TiO}_{2}$ & 0.38 & 0.54 \\
\hline $\mathrm{Al}_{2} \mathrm{O}_{3}$ & 12.74 & 12.69 \\
\hline $\mathrm{Fe}_{2} \mathrm{O}_{3}$ & 4.57 & 6.46 \\
\hline $\mathrm{MnO}$ & 0.15 & 0.18 \\
\hline $\mathrm{MgO}$ & 0.09 & 0.14 \\
\hline $\mathrm{CaO}$ & 0.68 & 1.01 \\
\hline $\mathrm{Na}_{2} \mathrm{O}$ & 5.29 & 5.45 \\
\hline $\mathrm{K}_{2} \mathrm{O}$ & 4.99 & 4.71 \\
\hline $\mathrm{P}_{2} \mathrm{O}_{5}$ & 0.08 & 0.06 \\
\hline LOI & 0.69 & 0.33 \\
\hline Total & 99.99 & 99.99 \\
\hline $\mathrm{Ba}$ & 261 & 670 \\
\hline $\mathrm{Sr}$ & 17.7 & 79 \\
\hline $\mathrm{Nb}$ & 86 & 86.5 \\
\hline $\mathrm{Zr}$ & 586 & 554 \\
\hline
\end{tabular}

by abundant and fragmented crystals with less euhedral terminations. Crystaloclasts exceed 65 vol. \% of the total phenocrysts abundance with intense resorption features. The fragments are dominated by small, equant, anhedral chunks of splinters. Devitrification processes include spherulitic growth (Fig. 4b) and development of micropoikilitic textures in a glassy groundmass. The pumice rich in crystals are collapsed, or stretched (fiamme) and are found moulded against, or form flow bands around, the crystals. The minerals observed are abundant sanidine crystals (up to $60 \mathrm{vol}$ \%) prevailing over quartz $(>40 \%)$. These minerals are associated with strongly welded and deformed glass shards. The lithic fragments consist mainly of cognate pyroclasts represented by porphyritic and aphyric non-vesicular glassy clasts.

\subsection{Whole-rock geochemistry}

Whole-rock geochemical data (Tab. 1) show that the rocks are acidic (rhyolitic) and peralkaline (Fig. 5a-b)

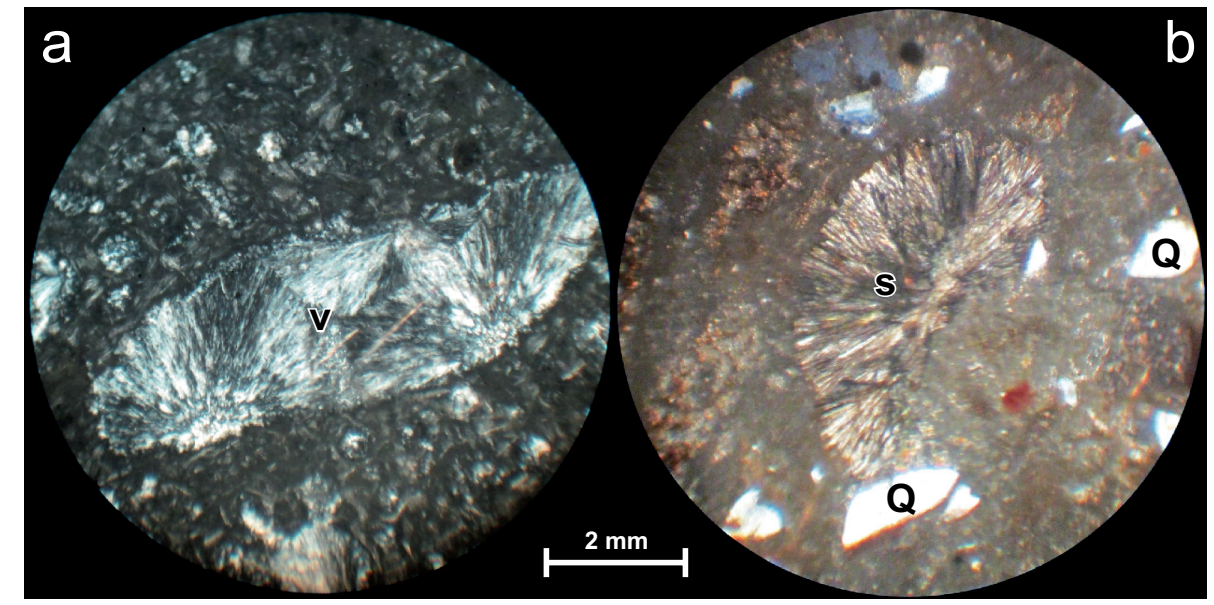



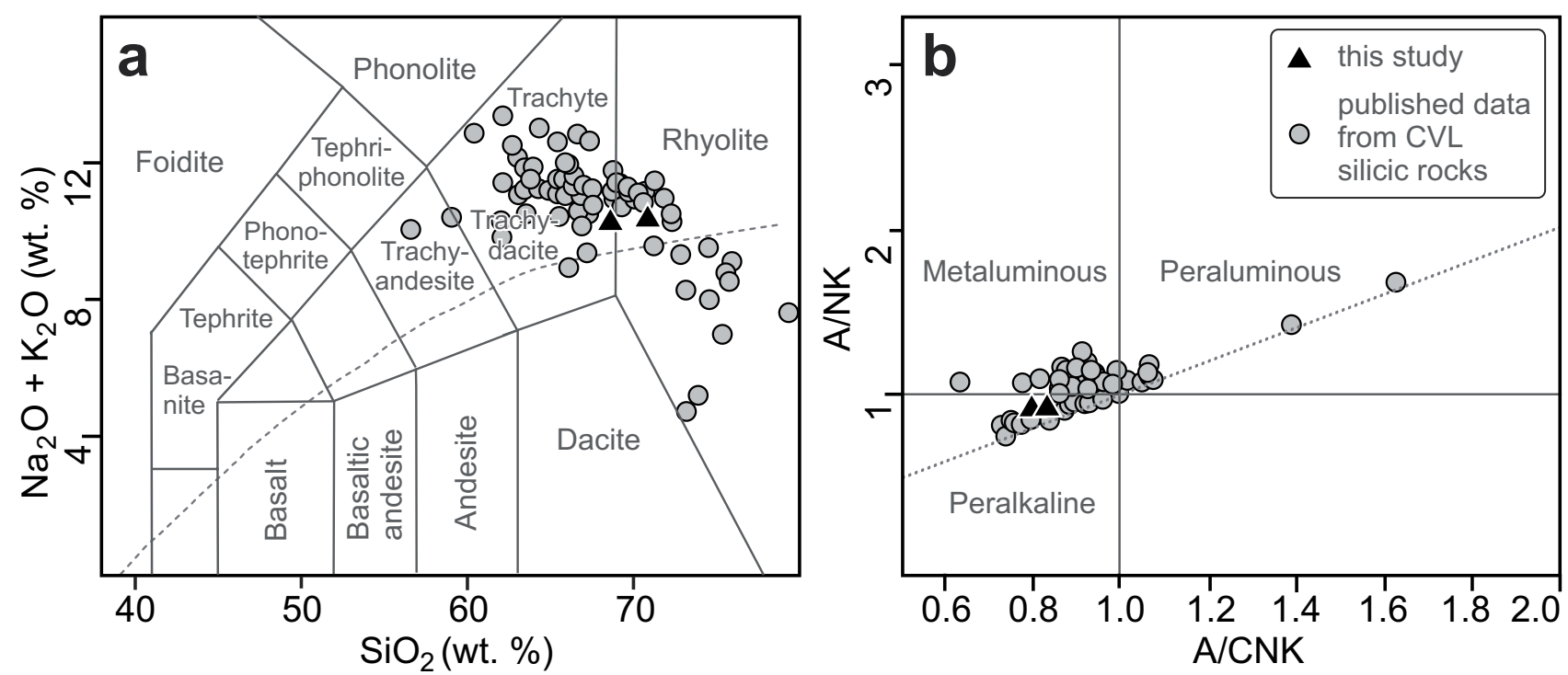

Fig. 5 Classification diagrams: a - Total alkali-silica (TAS) diagram (Le Bas et al. 1986); b - A/CNK vs. A/NK diagram (Shand 1943). New data are compared with published analyses of silicic volcanic rocks from the CVL (Marzoli et al. 1999; Ngounouno et al. 2000; Kamgang et al. 2010; Mbowou et al. 2015).

and resemble other felsic volcanic rocks along the CVL (e.g., Marzoli et al. 1999; Ngounouno et al. 2000; Kamgang et al. 2010; Mbowou et al. 2015). However, the studied samples have higher $\mathrm{K}_{2} \mathrm{O}$ and $\mathrm{Na}_{2} \mathrm{O}$ contents than rhyolites from Lake Chad area that are peraluminous in composition. The $\mathrm{Ba} / \mathrm{Nb}$ ratios for samples CMR01 and CMR02 are distinct (3.03 and 7.75, respectively), whereas the $\mathrm{Zr} / \mathrm{Nb}$ ratios show no significant difference (6.8 and 6.4 respectively).

\subsection{Zircon textures}

The dated samples representing the two facies (rhyolitic ignimbrite: CMR01 and autobreccia: CMR02) contain stubby, subhedral-euhedral zircons, in a few cases exhibiting rounded terminations (Fig. 6a-b). Internal structure of the dated 57 zircon grains was characterized in terms of the zoning (oscillatory and/or sector), CL intensity, presence of corrosion (resorption/dissolution) and recrystallization surfaces as well as mineral and/or melt inclusions.

The zircons are of two categories; those with core-rim contrast and those without it. Most zircons with clear core-rim structure show either blurred or strong oscillatory zoning (e.g. Fig. 6a: CMR01_1; Fig 6b: CMR02_22) indicative of igneous origin. A few grains show resorbed cores (e.g. CMR01_13). Zircons without core-rim structure have irregular patchy internal texture (e.g. Fig. 6a: CMR01_22). Other zircons exhibit sector zoning (e.g. Fig. 6a: CMR01_14, 24b, and 23; Fig. 6b: CMR02_23, 24, 27, and 28) or fir-tree zoning (Fig. 6b: CMR02_16). Several types of zircons have also been identified based on CL intensity. There are zircons with CL-dark cores and bright rims (e.g. CMR01_4, 10, 13, 17, 21, 23), bright whole grains (e.g. CMR01_3, 18, 25; CMR02_4, $5,13,19$ and 26), and moderate to high luminescence (e.g. CMR01_5, 11, 12, 14, 16, 20, 22; CMR02_2, 11 and 27). Some grains are characterised by high to moderate (light to grey) CL intensity zones which alternate with dark ones (e.g. CMR01_1 and 8; CMR02 12, 25 and 34). These CL zoning patterns show characteristics of both normal and reverse zoning. Normally zoned have U-rich cores surrounded by U-poor rims, whereas reversely zoned ones exhibit the opposite. Dark patches in some grains are suspected to be unidentified mineral or melt inclusions around which recrystallization zones characterized by high CL intensity (e.g. CMR01_8, 11, 12 and 14; CMR02_2, 21, 22 and 23) developed.

Brightness contrasts in the zircons are generally explained as a function of $U$ content, with high- $U$ zones corresponding to dark zones of crystals (Miller and Wooden 2004; Terentiev et al. 2016). In the present case, the $\mathrm{CL}$ images indicate that $\mathrm{U}$ concentration ranges widely both within and between grains.

\section{4. $U-P b$ zircon dating}

The $\mathrm{U}-\mathrm{Pb}$ ages obtained from 51 grains together with $\mathrm{U}$ and $\mathrm{Th}$ concentrations for zircons analyzed are given in Tab. 2. The U content of the zircons is on average slightly higher in sample CMR01 (74-1153 ppm) than in CMR02 (73 to $406 \mathrm{ppm}$ ). Thorium contents show similar pattern to $\mathrm{U}$. The $\mathrm{Th} / \mathrm{U}$ ratios (Tab. 2 ) are on average slightly lower in sample CMR01 (0.08-1.37 than in CMR02 (0.78-1.40).

Five analyses in sample CMR01 (nos 9, 14, 18, 21 and 22) and two in sample CMR02 (nos 1 and 2) 
yielded older, nearly concordant ages. Their degree of discordance calculated as $\left[1-\left({ }^{206 / 238} \mathrm{Age} /{ }^{207 / 206} \mathrm{Age}\right)\right] \times 100$ is well within $3.6 \%$. These grains probably represent inherited zircons taken up by the magma during its ascent. ${ }^{207} \mathrm{~Pb} /{ }^{206} \mathrm{~Pb}$ ages are used here to interpret zircons older, and ${ }^{206} \mathrm{~Pb} /{ }^{238} \mathrm{U}$ ages younger, than $1 \mathrm{Ga}$. Following this, xenocrystic zircons with Precambrian ${ }^{207} \mathrm{~Pb} /{ }^{206} \mathrm{~Pb}$ ages (CMR01_9, 1951 15 Ma; CMR01_14, $2123 \pm 14 \mathrm{Ma}$; CMR01 21, 2025 $\pm 17 \mathrm{Ma}$ ) and ${ }^{206} \mathrm{~Pb} /{ }^{238} \mathrm{U}$ ages (CMR01_18, $c$. $401 \mathrm{Ma}$ and CMR01 22, c. 556 $\mathrm{Ma})$ were observed from the rhyolitic autobreccia. In contrast, a younger inherited zircon age population at $\sim 150 \mathrm{Ma}$ (CMR02_1 and CMR02_2) occurs in the rhyolitic ignimbrite.

All the remaining zircons belong to a young, magmatic zircon population with ${ }^{206} \mathrm{~Pb} /{ }^{238} \mathrm{U}$ ages spanning from $\sim 26$ to $\sim 23 \mathrm{Ma}$. For these analyses, Concordia diagrams (Fig. 7) show arrays of data with lower intercepts at c. $23 \mathrm{Ma}$ and geologically meaningless upper intercepts at c. 4.9-5.0 Ga. More precisely, the Concordia age of the rhyolitic autobreccia CMR01 is $22.98 \pm 0.28$ Ma $(M S W D=6.8 ; \mathrm{n}=28-$ Fig. 7 a), i.e. very similar to $23.34 \pm 0.34$ Ma obtained for the ignimbrite CMR02 $(\mathrm{MSWD}=$ $4.6 ; \mathrm{n}=23$ - Fig. 7b).

\section{Discussion}

\subsection{Zircon ages spectra}

Theoretically, temporal heterogeneities in the zircon dates in the Sabga area may have resulted from $\mathrm{Pb}$ loss, common $\mathrm{Pb}$ incorporation, presence of

Fig. 6 Representative cathodoluminescence images of zircons in the studied samples: a - rhyolitic autobreccia, and $\mathbf{b}$ - rhyolitic ignimbrite. The first grain in each image is $\sim 30$ micrometres across, other grains are scanned at the same scale. older xenocrystic cores or prolonged crystallization of zircons in the magma reservoir, forming a mixture of juvenile magmatic phenocrysts and antecrysts (Miller et al. 2007).

The occurrence of zircons with uniform crystallization ages dominated by the younger discordant population between $\sim 25$ and $\sim 22 \mathrm{Ma}$, combined with an observed
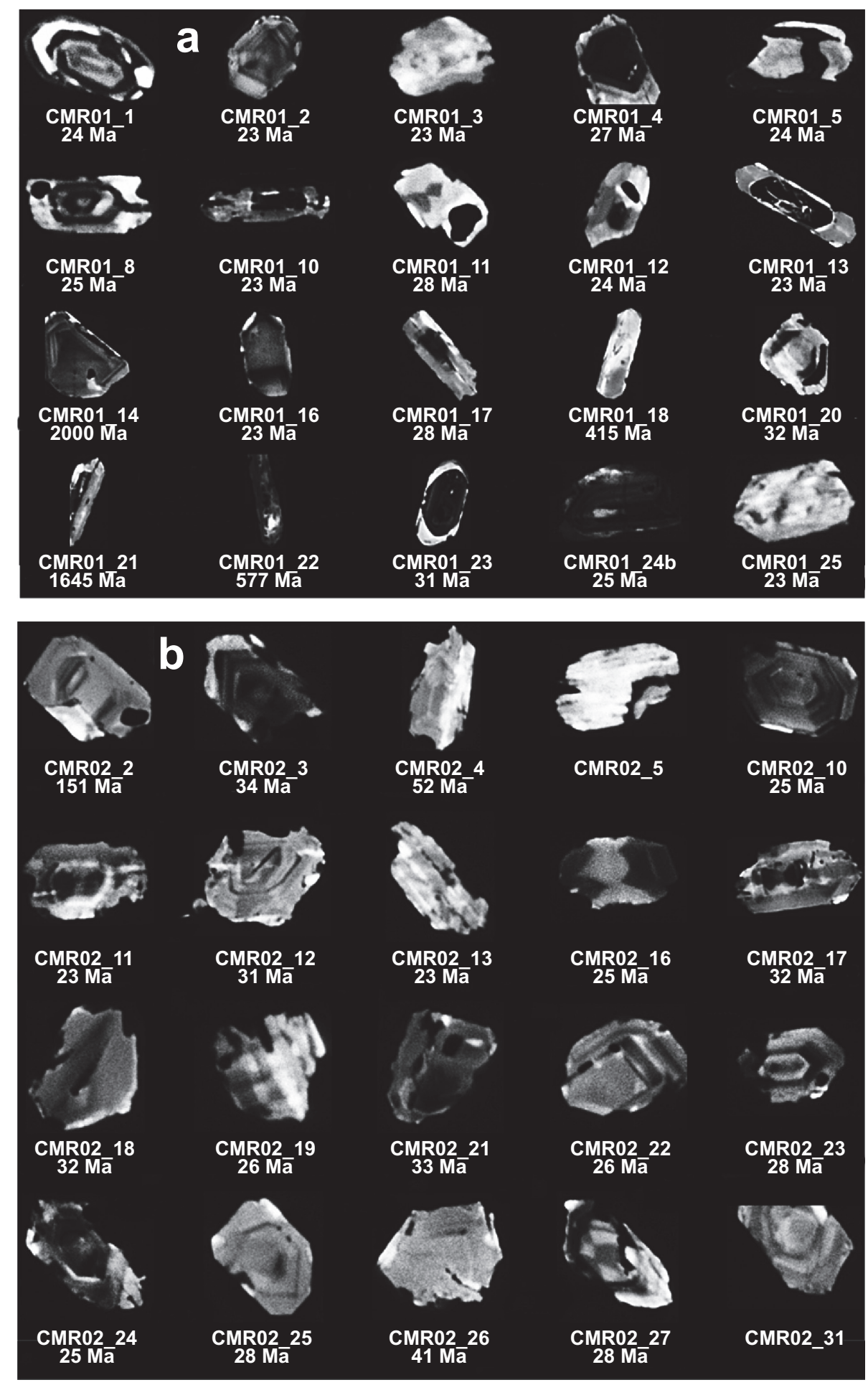


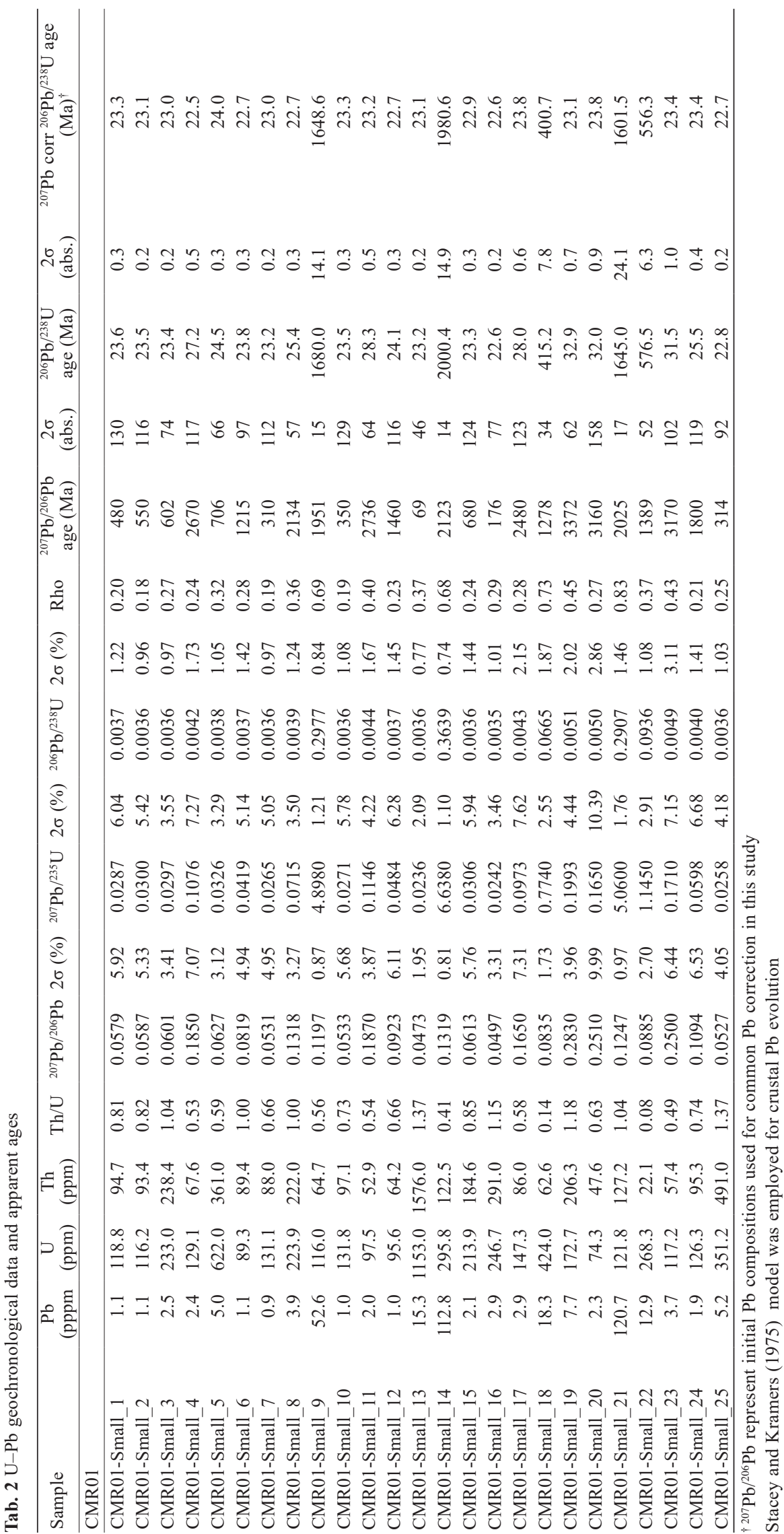

prominent peak at $\sim 23 \mathrm{Ma}$ in the rhyolitic autobreccia and ignimbrite, implies that the zircons were sourced from a common mush zone (Wilson and Charlier 2009) at Oligocene-Miocene times.

The upper intercept ages of $c$. 4.9-5 Ga suggest mixing of radiogenic with common $\mathrm{Pb}$ during crystallization of zircon in this magmatic chamber. The composition of terrestrial $\mathrm{Pb}$ (Stacey and Kramers 1975) calculated at 23 Ma (age of intrusion, i.e. lower intercept of the population) gives ${ }^{207} \mathrm{~Pb} /{ }^{206} \mathrm{~Pb}$ of 0.8372 , which translates to an age of c. 4,986 Ma. This corresponds, within error, to the values of the upper intercept ages observed here.

Single zircon data for the rhyolitic units in the Sabga area have revealed, besides the mixing array with common lead, seven inherited grains. These xenocrystic zircons could have been incorporated during assimilation or partial melting of local country rocks (e.g., Charlier et al. 2005; Miller et al. 2007; Wilson and Charlier 2009; Frazer et al. 2014; Barker et al. 2014). The zircons with Neoproterozoic (c. $577 \mathrm{Ma}$ ) and Paleoproterozoic (1645-2025 Ma) ages attest to the presence of older basement beneath the Bamenda Highland. Indeed, previous works (e.g., Toteu et al. 1994; Van Schmus et al. 2008) had reported the presence of the Neoproterozoic basement beneath the CVL.

However, the older zircon ages presented in the current paper also reveal the presence of an older basement and thus provide evidence for extensive crustal recycling in the region. This should further contribute to the discussion on the role of the PanAfrican continental crust in the genesis of felsic lavas and ignimbrites of the CVL although this theme is beyond the scope of the current paper. 
Petrology and geochronology of felsic volcanics in the Sabga area (Bamenda Highlands, Cameroon)

The single ages between $c .150 \mathrm{Ma}$ and c. $24 \mathrm{Ma}$ obtained here indicate two separate crystallization events separated by a gap. This also suggests that, although volcanic eruptions along the CVL commenced in Cretaceous with the eruption of felsic units at $69.4 \pm 0.4 \mathrm{Ma}$ in the Lake Chad area (Mbowou et al. 2012), the magmatic activity might have started elsewhere already at the JurassicCretaceous boundary, at c. 140-150 Ma.

Similar magmatic ages to those obtained in this study have been reported from basaltic lavas at Mt. $\mathrm{Oku}(31.0 \pm 1.0$ and $23.00 \pm 0.92 \mathrm{Ma}$; Njilah et al. 2004 and references therein) and silicic eruptive products at Adamawa Plateau $(32.60 \pm 0.76 \mathrm{Ma}$ and $34.40 \pm 0.80 \mathrm{Ma}$; Itiga et al. 2013). This implies that, during the eruption of basaltic rocks at Mt. Oku at $\sim 31 \mathrm{Ma}$ and silicic eruptions in the Adamawa Plateau at $33 \mathrm{Ma}$, magma was already undergoing cooling and crystallization within the magma chamber beneath the Bamenda Highlands.

The silicic eruptions at Sabga were synchronous to the later basaltic eruption of Mt. Oku at $23.00 \pm 0.92 \mathrm{Ma}$. This could also mean that intermittent pulses of new magmas were constantly being generated

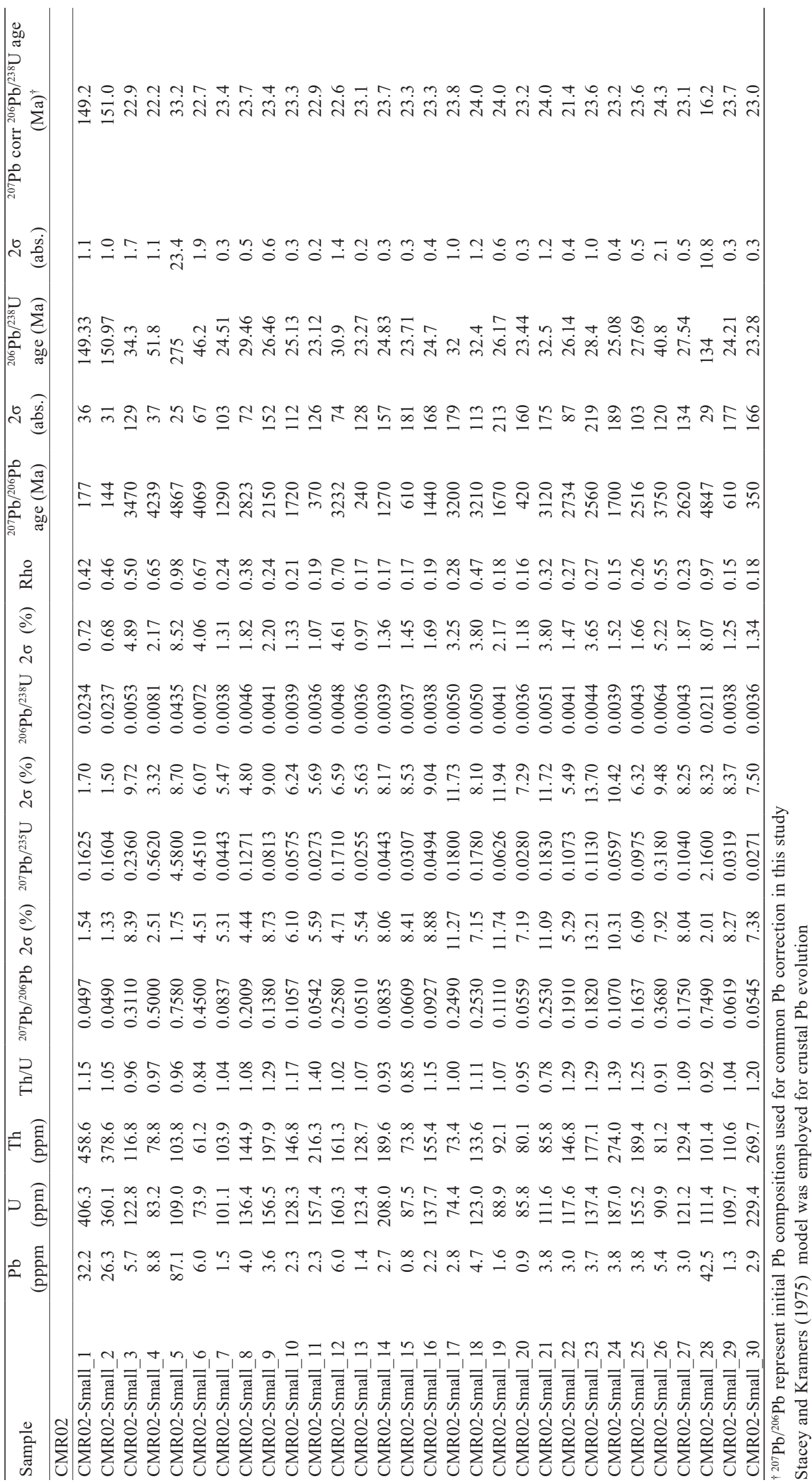


Data-point error ellipses are $2 \sigma$

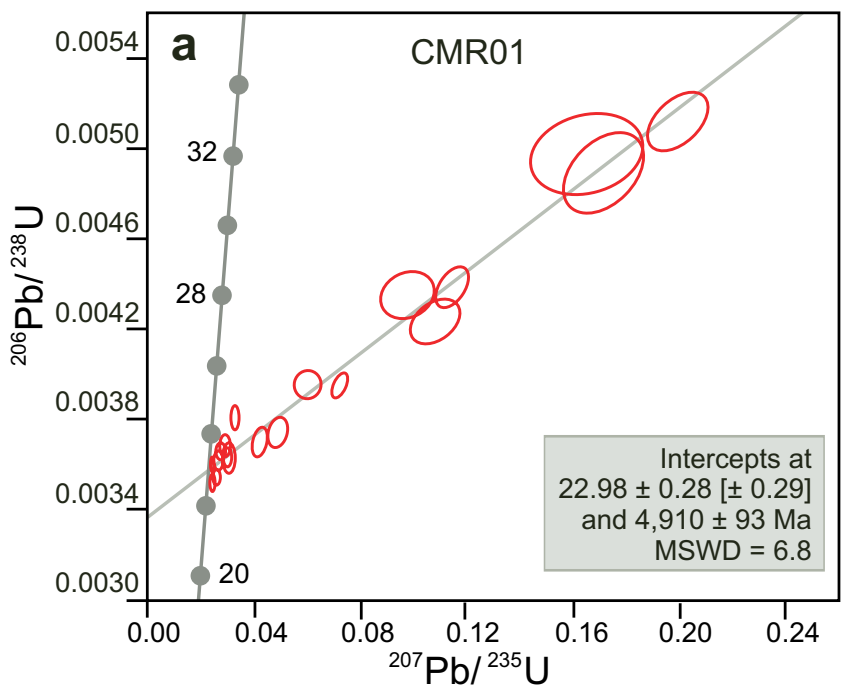

Data-point error ellipses are $2 \sigma$

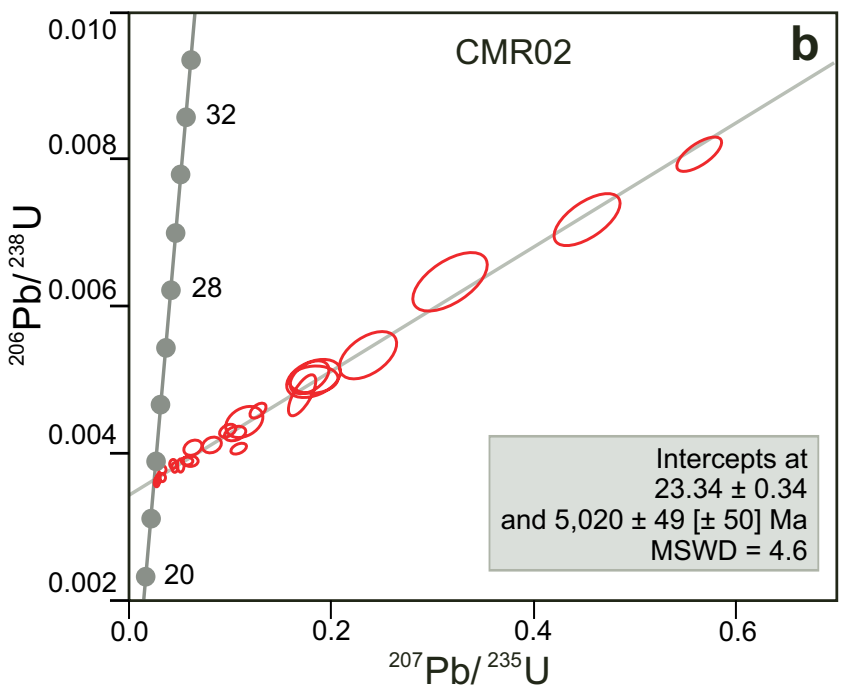

Fig. 7 Concordia diagrams showing the results of LA-ICP-MS U-Pb dating of studied samples: a - Concordia data from rhyolitic autobreccia (CMR01); b - Concordia data from rhyolitic ignimbrite (CMR02). Data-point error ellipses are $2 \sigma$.

and transported to the magma storage region where they partially crystallized within short time spans (Simon et al. 2014). Such magma batches could be partially reactivated upon the arrival of a new magma batch. This is evident in the extended crystallization ages for the zircons, which show variable shapes indicating corrosion, resorption and recrystallization as a result of their interaction with recharged magma.

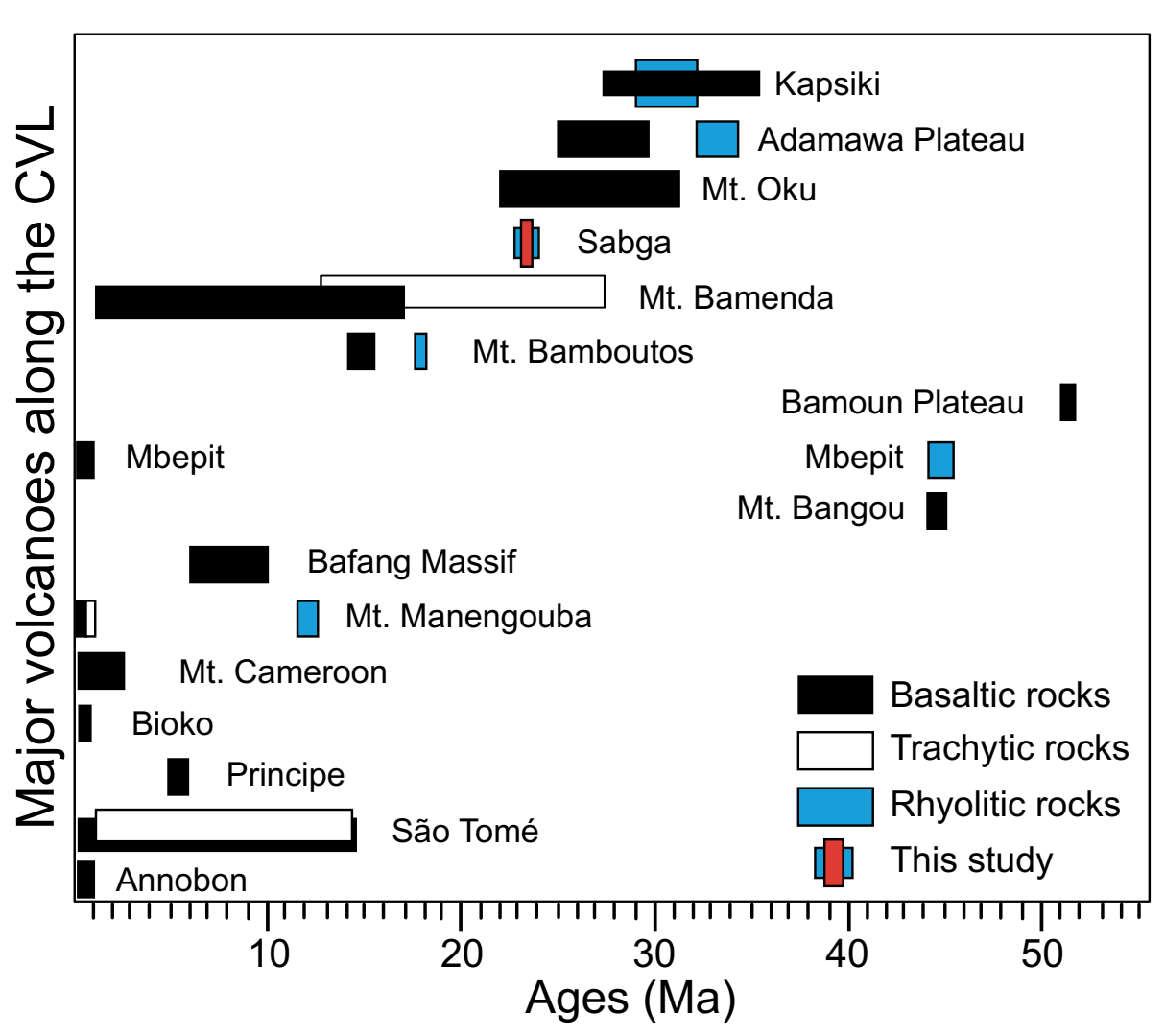

\subsection{Age variation of volcanic rocks along the CVL}

Numerous authors have previously used $\mathrm{K}-\mathrm{Ar}$ and $\mathrm{Ar}-\mathrm{Ar}$ techniques to date volcanics along the CVL (e.g. Dunlop and Fitton 1979; Marzoli et al. 1999, 2000; Ngounouno et al. 2003; Aka et al. 2004; Fosso et al. 2005; Njilah et al. 2007; Wandji et al. 2008; Kamgang et al. 2010, 2013; Mbowou et al. 2012; Itiga et al. 2013; Tchuimegnie Ngongang et al. 2015). These works have shown that the ages along the CVL range from $69.4 \pm 0.4 \mathrm{Ma}$ to Present (Fig. 8). However, most of these previous studies relied on samples collected over wide areas at each eruptive center without an established stratigraphic sequence. In this study we dated two units within a well-logged rock sequence in order to place the ages within a lithostratigraphic bracket. The new zircon LA-ICP-MS

Fig. 8 Summary of available $\mathrm{K}-\mathrm{Ar}$ and $\mathrm{Ar}-\mathrm{Ar}$ age data from the Cameroon Volcanic Line (basaltic and felsic rocks). Data sources: Gouhier et al. (1974), Dunlop (1983), Marzoli et al. (1999), Aka et al. (2004), Youmen et al. (2005), Kamgang et al. (2007, 2008, 2010, 2013), Wandji et al. (2008), Mbowou et al. (2012), Itiga et al. (2013). 
ages presented here are also more precise, constraining the ages for the two felsic rock units in the Sabga area at $\sim 23.0 \pm 0.3 \mathrm{Ma}$. This age is interpreted as the time of crystallization of the zircons and corresponds broadly to the emplacement ages of the rhyolitic rocks. Marzoli et al. (1999) reported an emplacement age of $\sim 23.0 \pm 0.04$ $\mathrm{Ma}(\mathrm{Ar}-\mathrm{Ar})$ for the lower felsic unit (rhyolitic) from a lava flow in the western end of the Sabga area. This implies that the emplacement of felsic lavas at various eruption sites in the Sabga area coincided broadly with the generation of rhyolitic autobreccia $(22.98 \pm 0.28 \mathrm{Ma})$ and the rhyolitic ignimbrite $(23.34 \pm 0.34 \mathrm{Ma})$ as documented in this study.

The basaltic rocks sandwiched by the dated felsic units therefore had to have an age intermediate between those reported above and thus all had to be emplaced within a very short time span. However, the basaltic lava flows in the Sabga area are older than proposed by Gouhier et al. (1974) in the Adamawa Plateau, Kamgang et al. (2013) in the Bamenda Highlands, Tchuimegnie Ngongang et al. (2015) in the Bafang area, that range from 1.0 to 17.6 $\mathrm{Ma}$ for the continental and from 0.08-5.88 Ma (Dunlop and Fitton 1979 and references therein; Aka et al. 2004) for the oceanic (Annobon, São Tomé and Principe) parts of the CVL. Compared to other basaltic rocks along this line, the studied basaltic unit is younger than the transitional basalts in the western part of the Bamoun Plateau (51.8 $\pm 1.2 \mathrm{Ma}$; Moundi et al. 2007), Mt. Bangou (44.7 $\pm 1.0 \mathrm{Ma}$; Fosso et al. 2005) and at Mt. Oku (31.0 $\pm 1.0 \mathrm{Ma}$; Njilah et al. 2004 and references therein), Ngaoundere Plateau (25.00-27.54 $\pm 0.66 \mathrm{Ma}$; Itiga et al. 2013). This suggests that there is no systematic age progression for basaltic rocks in the southern end of the CVL.

Similarly, the current ages obtained for the felsic units are younger than those dated in Mt. Mbepit $(44.0 \pm 1.0$ to $45.5 \pm 1.1 \mathrm{Ma}$; Wandji et al. 2008); in the Ngaoundere Plateau ( $32.60 \pm 0.76$ to $34.4 \pm 0.8 \mathrm{Ma}$; Itiga et al. 2013) and in the Kapsiki area (29.0-32.0 $\pm 0.5 \mathrm{Ma}$; Dunlop 1983). Although the Sabga rhyolites are younger than the above-mentioned felsic units, they are older than the trachytes of Manengouba (0.7 $\pm 0.1 \mathrm{Ma}$; Youmen et al. 2005), the trachytes $(16.06-16.23 \pm 0.06 \mathrm{Ma})$ and rhyolites (15.4-18.0 Ma) of Mt. Bambouto (Youmen et al. 2005; Marzoli et al. 1999), trachytes of São Tomé (0.7-13.25 $\pm 0.45 \mathrm{Ma}$; Fitton and Dunlop 1985 with references therein) and the trachytes of Ngaoundere Plateau $(9.8 \pm 0.2$ to $11.39 \pm 0.03 \mathrm{Ma}$; Gouhier et al. 1974). This implies that there is a general trend for silicic rocks that are younging to the SW along the CVL, i.e. from Lake Chad to São Tomé. But in the Adamawa Plateau the felsic units dated in previous studies are younger than those dated here (see also Fitton and Dunlop 1985; Marzoli et al. 1999, 2000; Aka et al. 2004; Kamgang et al. 2010).
However, volcanism in Sabga and Oku areas has been synchronous when the ages obtained in this study are compared to the ages of rhyolites $(23.05 \pm 0.05 \mathrm{Ma}$ to $23.3 \pm 0.5 \mathrm{Ma})$ and basalts $(22.90 \pm 1.00 \mathrm{Ma}-23.00 \pm 0.92$ Ma) of Mt. Oku dated by Gouhier et al. (1974).

\subsection{Magma-chamber processes}

External morphology and internal zoning in zircon can be potentially linked to complex magma evolution trajectories from initial formation by source melting, through various stages of movement through the crust, contamination and mixing with different magma batches, fractional crystallization, with loss of cumulates and vapour and extrusion (Corfu et al. 2003). These processes are examined here for the current case.

\subsubsection{Rejuvenation and melt segregation timescales}

Rejuvenation, that is a process of reheating, re-melting and melt extraction, has been suggested in many silicic magmatic systems (e.g., Molloy et al. 2008; Girard and Stix 2009; Bégué et al. 2014) with the main trigger being either a fresh basaltic intrusion or an interaction of magma with tectonic stresses.

In the Sabga area, rejuvenation seems to have followed the extraction of the older rhyolitic ignimbrite. The existing crystal mush left beneath this volcanic area could have been reactivated by a fresh pulse of a hot mantle-derived melt, as evidenced by the basaltic intrusion sandwiched between the felsic units. This rejuvenation led consequently to the emplacement of the younger rhyolitic autobreccia.

Zircon often preserves textural evidence of repeated dissolution and crystallization (growth) surfaces, reflecting magma recharge and subsequent rejuvenation (Miller and Wooden 2004). The zircons would dissolve following injection of basaltic magma and subsequently resume growth once magma cools down below the zircon saturation temperature. Zircon CL images of our rhyolitic samples reveal the presence of inherited cores in some grains. This, combined with the presence of antecrysts in the younger rhyolitic autobreccia sample, jointly suggests the process of reheating, remelting and melt extraction beneath the Sabga area. Mafic input in many large silicic ignimbrite-forming eruptions has been suggested as a trigger of rejuvenation and subsequent eruptions (Manga and Brodsky 2006; de Silver and Gosnold 2007). This is evident in resorbed and partly rounded basaltic clasts observed within the ignimbrite.

Before an eruption, magma accumulation processes can occur on timescales as short as decades and whole magma systems can be rebuilt over millions of years 
(Wilson and Charlier 2016). In such periodically recharged magma storage systems, the melt segregation timescales can be relatively fast $\left(\sim 10^{4}-10^{5}\right.$ years; Béqué et al. 2014). However, Allan et al. (2013) provided evidence for much shorter timescales of $c .3000$ years for melt accumulation at the Oruanui magma (Taupo Volcanic Zone). Such timescales are supported by the works of Chamberlain et al. (2014) on the Bishop Tuff with magma accumulation timescale of over c. $80 \mathrm{ka}$ (Gualda et al. 2012).

The melt segregation timescales for the Sabga area between samples CMR01 and CMR02 are not fully resolvable and within errors, the ages for both samples are identical. In any case, they could not be longer than several hundreds of years. This is within the timeframe for most silicic volcanoes with super-eruption (Gualda et al. 2012; Chamberlain et al. 2014). Therefore, if we consider that the dated horizons at Sabga represent two temporally distinct melt extraction episodes, these would have to be in rapid succession, suggesting very efficient melt extraction from the crystal mush, and, consequently efficient rejuvenation of this mush. The short time window needed to extract the melt could also be one of the reasons for the presence of isolated magma batches. This, in turn, suggests that there was not enough time for amalgamation of the different batches into either a single large magma body or two separate magma chambers located below the Sabga center. This also explains the existence of mafic (basaltic) units sandwiched between the dated rhyolitic lavas. If mixing was rampant, intermediate lavas would have erupted rather than these compositionally distinct end members.

\subsubsection{Fractional crystallization}

Magmatic crystallization processes can be deciphered using zircon features such as typical growth zoning, sector zoning and presence of overgrowths (Corfu et al. 2003; Ji et al. 2009; Terentiev et al. 2016). In the Sabga area, some of the zircon grains (Fig. 6a; CMR01_1, 8) with reverse zoning are indicative of multiple episodes of magma recharge with continuous crystallization of zircon into bright cores and dark rims as the magma evolved by fractional crystallization. In addition, some of the zircon grains providing the age of the flow emplacement have dark cores, bright overgrowths and the highest $\mathrm{U}$ content amongst all the zircons analysed. This is consistent with the presence of a highly evolved magma with high $\mathrm{U}$ content prior to eruption. The continuous zoning with sharp crystal-phase controlled boundaries between CL-bright and CL-dark zircon growth zones (Fig. 6a; CMR01_1, 8) indicates an abrupt change in physicochemical conditions during crystallization (Corfu et al. 2003). Also, grains with U-rich cores have been shown by Miller and Wooden (2004) to indicate that high-silica rhyolites might have been present early in the development of the system and recycled in later rhyolite magma similarly to zircon grain CMR02-13 observed in Sabga area. Indeed, decreasing whole-rock concentrations of $\mathrm{Ba}$ and $\mathrm{Sr}$ with increasing $\mathrm{SiO}_{2}$ reflect plagioclase and alkali feldspar fractionation in felsic rocks along the CVL (Ngounounou et al. 2000; Njilah et al. 2004; Kamgang et al. 2010, 2007).

\subsubsection{Crustal contamination and magma mingling}

Zircons with corrosion edges and resorption zones are taken here as an evidence of a late-stage heating resulting from mingling of new batches of hot mafic melt with residual silicic magma in the original magma chamber. Numerous authors, dealing either with magma mixing or crustal contamination, have demonstrated such processes worldwide (e.g., Vavra 1994; Gagnevin et al. 2010; Chamberlain et al. 2014). For instance, according to Erdmann et al. (2013) and Miller and Wooden (2004), such dissolution textures in zircons can be accounted for by country-rock contamination with xenocrystic zircons. These zircons could be inherited from the melting of the crust or entrained from country rocks. Explosive eruptions can remobilize older country rocks, the solidified part of the feeding channels or can even involve older tephras from the surface (e.g., Charlier et al. 2005; Wilson and Charlier 2009; Frazer et al. 2014; Barker et al. 2014). However, the presence of the Pan-African basement beneath the studied region can be the only confirmed source of the Neoproterozoic grains which is also evidence of crustal recycling within the Bamenda Highlands.

In addition, in the Sabga area, high $\mathrm{Zr} / \mathrm{Nb}$ ratios (6.8 and 6.4), high $\mathrm{Ba}$ (261 and $670 \mathrm{ppm}$ ), and low $\mathrm{Sr}$ (17.7 and $79 \mathrm{ppm}$ ) concentrations for CMR01 and CMR02 respectively attest to the partial assimilation of local country rocks. This contradicts the previous works on felsic lavas along the CVL (e.g. Franz et al. 1999; Ngounouno et al. 2000; Peccerillo et al. 2007) reporting low Ba (10-107 ppm) and $\mathrm{Zr} / \mathrm{Nb}(2.4-4.5)$.

Crustal contamination had been initially not considered a significant petrological process in the evolution of felsic units in the continental segment of the CVL (e.g., Fitton 1987; Ngounouno et al. 2000; Rankenburg et al. 2004). However, Wotchoko et al. (2017) recently showed that trachyte pumice and rhyolite lava evolved through crustal contamination $(\mathrm{Zr} / \mathrm{Nb}=4.5-6.0$, $\mathrm{Zr}=500-1000 \mathrm{ppm}$ ).

The Sabga area is characterised by an alternation of felsic and basaltic units with no evidence of intermediate rock suites. This gap is similar to other volcanic centers in the Continental segment of the CVL. However, the recent age data have shown that basaltic and felsic units 
most likely originate independently. Separate batches of rhyolitic magmas are generated and extracted from the intermediate crystal mush, and rapidly extruded. Therefore, the presence of crystal mushes along the continental segment of the CVL could account for the Daly gap. The volcanic activity in Sabga is characterised by multiple eruption episodes through diverse vents. Felsic volcanism, which is dominantly the oldest unit, commenced with low column explosive pyroclastic flow eruption producing lava-like ignimbrites probably due to retention of magmatic heat facilitating coalescence, flow, and primary crystallization. This was later followed by more effusive eruptions producing lava flows.

\section{Conclusions}

This study attempts to better constrain an age bracket for a basaltic unit in the Sabga area (Bamenda Highlands, Cameroon Volcanic Line) sandwiched by two rhyolite units, dated by zircon $\mathrm{U}-\mathrm{Pb}$ geochronology. The ages of the rhyolitic ignimbrite and rhyolitic autobreccia stand at $23.3 \pm 0.3 \mathrm{Ma}(23.34 \pm 0.34 \mathrm{Ma}$ and $22.98 \pm 0.28 \mathrm{Ma}$, respectively) indicating two separate eruption episodes emplaced in a rapid succession. We propose that a longlived silicic magma reservoir, mostly kept as a highly crystalline mush, has existed beneath the Sabga area with melt segregation timescales in order of several hundred thousands of years. The age distribution of zircon crystals within these samples suggests that crustal assimilation by surrounding country rocks took place together with the recycling of earlier crystallized zircons (antecrysts) within the crystal mush. Lastly, we infer the presence of an older (Paleoproterozoic) basement along the CVL in addition to the Pan-African basement previously identified.

Acknowledgements. This article was developed with support from the Cameroon government tuition-free grant for post-graduate students. It forms part of the $\mathrm{PhD}$. thesis of the first author who also acknowledges IRGM (Institute for Geological and Mining Research) for their material support and study leave granted. CES is supported by the research modernization grants from the Ministry of Higher Education, Cameroon. The authors are grateful to the journal reviewers Prof. Christoph Breitkreuz and Dr. Jiří Sláma for their insightful criticisms that significantly improved the clarity of this contribution. The editorial support of Dr. Vladislav Rapprich is also acknowledged.

\section{References}

Aka FT, Nagao K, Kusakabe M, Sumino H, Tanyileke G, Ateba B, Hell J (2004) Symmetrical helium isotope distribution on the Cameroon Volcanic Line, West Africa. Chem Geol 203: 205-223

Allan ASR, Morgan DJ, Wilson CJN (2013) From mush to eruption in centuries: assembly of the super-sized Oruanui magma body. Contrib Mineral Petrol 166: 143-164

Barker SJ, Wilson CJN, Smith EGC, Charlier BLA, Wooden JL, Hiess J, Ireland TR (2014) Post-supereruption magmatic reconstruction of Taupo (New Zealand), as reflected in zircon ages and trace elements. J Petrol 55: 1511-1533

Bégué F, Deering CD, Gravley DM, Kennedy BM, Chambefort I, Gualda GAR, Bachmann O (2014) Extraction, storage and eruption of multiple isolated magma batches in the paired Mamaku and Ohakuri eruption, Taupo Volcanic Zone, New Zealand. J Petrol 55: $1653-1684$

Chamberlain CJN, Wilson JL, Wooden JL, Charlier BLA, IRELAND TR (2014) New perspective on the Bishop Tuff from zircon textures, ages and trace elements. J Petrol 55: 395-426

Charlier BLA, Wilson CJN, Lowenstern JB, Blake S, VAN CALSTEREN PW, DAVIDSON JP (2005) Magma generation at a large, hyperactive silicic volcano (Taupo, New Zealand) revealed by $\mathrm{U}-\mathrm{Th}$ and $\mathrm{U}-\mathrm{Pb}$ systematics in zircons. J Petrol 46: 3-32

Chombong NN, Suh CE, Lehmann B, Vishiti A, Ilouga DC, Shemang EM, Tantoh BS, Kedia AC (2017) Host rock geochemistry, texture and chemical composition of magnetite in iron ore in the Neoarchaean Nyong Unit in southern Cameroon. Appl Earth Sci (Trans Inst Min Metall B) 126: 129-145

Corfu F, Hanchar JM, Hoskin PW, Kinny P (2003) Atlas of zircon textures. In: HANCHAR JM, HoskIN PWO (eds) Zircon. Mineralogical Society of America and Geochemical Society Reviews in Mineralogy and Geochemistry 53: 469-500

De Silva SL, Gosnold WD (2007) Episodic construction of batholiths: insights from the spatiotemporal development of an ignimbrite flare-up. J Volcanol Geotherm Res 167: $320-335$

DunLOP HM (1983) Strontium isotope geochemistry and potassium-argon studies on volcanic rocks from the Cameroon Line, West Africa. Unpublished PhD. Thesis, University of Edinburgh, pp 1-347

Dunlop HM, FitTon JG (1979) A K-Ar and Sr-isotopic study of the volcanic island of the Principe, West Africa - evidence for mantle heterogeneity beneath the Gulf of Guinea. Contrib Mineral Petrol 71: 125-131

ERdMANN S, WODICKA N, JaCKSON SE, CORRIGAN D (2013) Zircon textures and composition: refractory recorders of magmatic volatile evolution. Contrib Mineral Petrol 165: 45-71

FitTon J (1987) The Cameroon Line, West Africa: a comparison between oceanic and continental alkaline 
volcanism. In: FitTon JG, Upton BGJ (eds) Alkaline Igneous Rocks. Geological Society of London Special Publications 30: 273-291

FitTon JG, Dunlop HM (1985) The Cameroon Line, West Africa, and its bearing on the origin of oceanic and continental alkali basalt. Earth Planetary Sci Lett 72: 23-38

Fosso J, MÉnard JJ, BardintzefF J-M, WandJi P, Tchoua FM, BELLON H (2005) Mount Bangou lavas: primary volcanic manifestations of the Eocene with transitional affinity of the Cameroon Line. C R Geosci 337: 315-325

Franz G, Steiner G, Volker F, Pudio D, Hammerschmidt K (1999) Plume related alkaline magmatism in central Africa - the Meidob Hills (W Sudan). Chem Geol 157: $27-47$

Frazer RE, Coleman DS, Mills RD (2014) Zircon U-Pb geochronology of the Mount Givens Granodiorite: implications for the genesis of large volumes of eruptible magma. J Geophys Res: Solid Earth 119: 2013JB010716

GaGnevin D, DaLY JS, Kronz A (2010) Zircon textures and chemical composition as a guide to magmatic processes and mixing in a granitic environment and coeval volcanic system. Contrib Mineral Petrol 159: 579-596

GIRARD G, Stix J (2009) Buoyant replenishment in silicic magma reservoirs: experimental approach and implications for magma dynamics, crystal mush remobilisation, and eruption. J Geophys Res 114: B08203

Gouhier J, Nougier J, Nougier D (1974) Contribution à l'étude volcanologigue du Cameroun (Ligne du Cameroun-Adamaoua). Ann Fac Sci Univ Yaoundé, Cameroun 17: $3-48$

Gountie Dedzo M, Nedelec A, Nono A, Nuanko T, Font E, Kamgang P, Nuonfang E, Launeau P (2011) Magnetic fabrics of the Miocene ignimbrites from WestCameroon: implications for pyroclastic flow source and sedimentation. J Volcanol Geotherm Res 205: 113-132

Gualda GA, Pamukcu AS, Ghiorso MS, Anderson AT, Sutton SR, Rivers ML (2012) Timescales of quartz crystallization and the longevity of the Bishop giant magma body. PloS One 7: e37492

HENRY CD, WOLFF JA (1992) Distinguishing strongly rheomorphic tuffs from extensive silicic lavas. Bull Volcanol 54: 71-186

Horstwood MAS, KošLer J, Gehrels G, Jackson SE, McLean nM, Paton C, Pearson NJ, Sircombe K, Sylvester P, Vermeesch P, Bowring JF, Condon DJ, Schoene B (2016) Community-derived standards for LA-ICP-MS-(Th-)Pb geochronology - uncertainty propagation, age interpretation and data reporting. Geost Geoanal Res 40: 311-332

Houghton BF, Wilson CJN, McWilliams MO, LanPhere MA, Weaver SD, Briggs RM, Pringle MS (1995) Chronology and dynamics of a large silicic magmatic system: Central Taupo Volcanic Zone, New Zealand. Geology 23: 13-16
ITIGA Z, BARDINTZEFF J-M, WotchoKo P, WANDJI P, BELLON H (2013) Tchabal Gandaba Massif in the Cameroon Volcanic Line: a bimodal association. Arab J Geosci 7: 4641-4664

Ji W-Q, Wu F-Y, Chung S-L, Li J-X, Liu C-Z (2009) Zircon $\mathrm{U}-\mathrm{Pb}$ geochronology and $\mathrm{Hf}$ isotopic constraints on petrogenesis of the Gangdese batholiths, Southern Tibet. Chem Geol 262: 229-245

Kamgang P, Nuonfang E, Chazot G, Tchoua F (2007) Geochemistry and geochronology of felsic lavas from Bamenda Mountains (Cameroon Volcanic Line). C R Geosci 339: 659-666

Kamgang P, Chazot G, Nuonfang E, Tchoua F (2008) Geochemistry and geochronology of mafic rocks from the Bamenda Mountains (Cameroon): source composition and crustal contamination along the Cameroon Volcanic Line. C R Geosci 340: 850-857

Kamgang P, Nuonfang E, Nono A, Gountie Dedzo M, TCHOUA FM (2010) Petrogenesis of a silicic magma system: geochemical evidence from Bamenda Mountains, NW Cameroon, Cameroon Volcanic Line. J Afr Earth Sci 58: 285-304

Kamgang P, Chazot G, Nuonfang E, Ngongang NBT, TCHOUA FM (2013) Mantle sources and magma evolution beneath the Cameroon Volcanic Line. Geochemistry of mafic rocks from the Bamenda Mountains (NW Cameroon). Gondwana Res 24: 727-741

Klemetti EW, Clynne MA (2014) Localized rejuvenation of a crystal mush recorded in zircon. Temporal and compositional variation at the Lassen Volcanic Center, Northern California. PloS One 9: e113157

Kylander-Clark A, Hacker BR, Cottle JM (2013) Laser-ablation split-stream ICP petrochronology. Chem Geol 345: 99-112

Le Bas MJ, Le Maitre RW, Streckeisen A, Zanettin B (1986) A chemical classification of volcanic rocks based on the total alkali-silica diagram. J Petrol 27: 745-750

LuDWIG KR (2003) User's manual for Isoplot 3.0: A Geochronological Toolkit for Microsoft Excel. Berkeley Geochronology Center Special Publications 4: 1-71

MANGA M, BRODSKY E (2006) Seismic triggering of eruptions in the far field: volcanoes and Geysers. Ann Rev Earth Planet Sci 34: 263-291

Marzoli A, Renne PR, Piccirillo EM, Francesca C, Bellieni G, Melfi AJ, Nyobe JB, N'Ni J (1999) Silicic magmas from the continental Cameroon Volcanic Line (Oku, Bambouto and Ngaoundere): ${ }^{40} \mathrm{Ar}-{ }^{39} \mathrm{Ar}$ dates, petrology, $\mathrm{Sr}-\mathrm{Nd}-\mathrm{O}$ isotopes and their petrogenetic significance. Contrib Mineral Petrol 135: 133-150

Marzoli A, Piccirillo EM, Renne PR, Bellieni G, Lacumin M, NuOya JB, Tongwa AT (2000) The Cameroon Volcanic Line revisited: petrogenesis of continental basaltic magmas from lithospheric and asthenospheric mantle sources. J Petrol 41: 87-109 
Mbowou GiB, Lagmet C, Nomade S, Ngounouno I, Deruelle B, Ohnestetter D (2012) Petrology of the Late Cretaceous peralkaline rhyolites (pantellerite and comendite) from Lake Chad, Central Africa. J Geosci 57: $127-141$

Mвоwou GB, Botelho NF, Ngounouno I (2015) Geochemistry of Mn-bearing rocks hosted in rhyolites from Hadjer Bigli (SE Lake Chad, Cameroon): preliminary results. J Geosci 60: 163-170

McKinNey ST, CotTle JM, Ledgerer GW (2015) Evaluating rare earth element (REE) mineralization mechanisms in Proterozoic gneiss, Music Valley, California. GSA Bulletin 127: 1135-1152

Miller JS, Wooden JL (2004) Residence, resorption and recycling of zircons in Devils Kitchen Rhyolite, Coso Volcanic Field, California. J Petrol 45: 2155-2170

Miller JS, Matzel JeP, Miller CF, Burgess SD, Miller RB (2007) Zircon growth and recycling during the assembly of large, composite arc plutons. J Volcanol Geotherm Res 167: 282-299

Milner DM, Cole J, Wood CP (2003) Mamaku Ignimbrite: a caldera-forming ignimbrite erupted from a compositionally zoned magma chamber in Taupo Volcanic Zone, New Zealand. J Volcanol Geotherm Res 22: 243-264

Molloy C, Shane PA, NaIRn I (2008) Pre-eruption thermal rejuvenation and stirring of a partly crystalline rhyolite pluton revealed by the Earthquake Flat Pyroclastics deposits, New Zealand. J Geol Soc, London 165: 435-447

Moundi A, WanduI P, BardinTZEFF JM, MÉNARd JJ, OKomo Atouba LC, Mouncherou OF, Reusser E, Bellon H, TCHouA FM (2007) Eocene basalts with transitional affinity of Bamoun Plateau, proof of an enriched mantle reservoir beneath the Cameroon Volcanic Line. C R Geosci 339: 396-406

Ngounouno I, Déruelle B, Demaiffe D (2000) Petrology of the bimodal Cenozoic volcanism of the Kapsiki Plateau (northernmost Cameroon, central Africa). J Volcanol Geotherm Res 102: 21-44

Ngounouno I, Moreau C, Déruelle B, Demaiffe D, Montigny R (2003) Petrology of the Cenozoic volcanism in the Upper Benue Valley (northern Cameroon, Central Africa). Contrib Mineral Petrol 145: 87-106

Nillah IK, Ajonina HN, Kamgang KV, Tehindjang M (2004) K-Ar ages, mineralogy, major and trace element geochemistry of the Tertiary-Quaternary lavas from the Ndu Volcanic Ridge N.W. Cameroon. Afri J Sci Tech 5: 47-56

Nillah K, Temdim R, Richard C, Ghogomu N, TchuiTCHOU R, AJonina H (2007) Geochemistry of TertiaryQuaternary lavas of Mt. Oku, Northwest Cameroon. Rev Fac Ing Univ Antioquia 40: 59-75

Nuome MS, De Wit MJ (2014) The Cameroon Line: analysis of an intraplate magmatic province transecting both oceanic and continental lithospheres: constraints, controversies and models. Earth Sci Rev 139: 168-194
Nuome MS, Suh CE, Sparks RSJ, Ayonghe SN, Fitton JG (2008) The Mount Cameroon 1959 compound lava flow field: morphology, petrography and geochemistry. Swiss J Geosci 101: 85-98

OKEREKE CS (1988) Contrasting modes of rifting: the Benue Trough and Cameroon Volcanic Line, West Africa. Tectonics 7: 775-784

Paton C, Woodhead JD, Hellstrom JC, Hergt JM, Greig A, MaAs R (2010) Improved laser ablation U-Pb zircon geochronology through robust down hole fractionation correction. Geochem Geophys Geosyst 11: DOI 10.1029/2009GC002618

Peccerillo A, Donati C, Santo AP, Orlando A, Yirgu G, Ayalew D (2007) Petrogenesis of silicic peralkaline rocks in the Ethiopian rift: geochemical evidence and volcanological implications. J Afr Earth Sci 48: 161-173

Rankenburg K, Lassiter JC, Brey G (2004) Origin of megacrysts in volcanic rocks of the Cameroon volcanic chain - constraints on magma genesis and crustal contamination. Contrib Mineral Petrol 147: 129-144

Seitz S, Putlitz B, Baumgartner LP, Escig S, Meiborn A, Bouvier A-S (2016) Short magmatic residence times of quartz phenocrysts in Patagonian rhyolites associated with Gondwana breakup. Geology 44: 67-70

SELF S (2006) The effects and consequences of very large explosive volcanic eruptions. Philos Trans R Soc London, Ser A 364: 2073-2097

SHAND SJ (1943) Eruptive Rocks, Their Genesis, Composition, Classification, and Their Relations to Ore-Deposits, $2^{\text {nd }}$ ed. John Wiley and Sons, New York, pp 1-444

Simon J, Weis D, DePaolo D, Renne P, Mundil R, Schmitt A (2014) Assimilation of preexisting Pleistocene intrusions at Long Valley by periodic magma recharge accelerates rhyolite generation: rethinking the remelting model. Contrib Mineral Petrol 167:1-34

Singer BS, Andersen NL, Mével HL, Feigl KL, DeMets C, Tikoff B, Thurber CF, Jicha BR, Cardona C, Córdova L, Gil F, Unsworth MJ, Williams-Jones,G, Miller C, Fierstein J, Hildreth W, Vazquez J (2014) Dynamics of a large restless rhyolitic magma system, southern Andes, Chile. GSA Today 24: 4-10

StACEY JA, KRAMERS JD (1975) Approximation of terrestrial lead isotope evolution by a two-stage model. Earth Planet Sci Lett 26: 207-221

SuH CE, Luhr JF, Nuome MS (2008) Olivine-hosted glass inclusions from scoriae erupted in 1954-2000 at Mount Cameroon Volcano, West Africa. J Volcanol Geotherm Res 169: 1-33

Tchuimegnie Ngongang NB, Kamgang P, Chazot G, Agranier A, Bellon H, Monnotte P (2015) Age, geochemical characteristics and petrogenesis of Cenozoic intraplate alkaline volcanic rocks in the Bafang region, West Cameroon. J Afr Earth Sci 102: 218-232 
Terentiev RA, Skryabin VY, SANTOSH M (2016) U-Pb zircon geochronology and geochemistry of Paleoproterozoic magmatic suite from East Sarmatian Orogen: tectonic implications on Columbia supercontinent. Precambr Res 273: 165-184

Toteu SF, Van Schmus WR, Penaye J, Nyobe JB (1994) $\mathrm{U}-\mathrm{Pb}$ and $\mathrm{Sm}-\mathrm{Nd}$ evidence for Eburnian and PanAfrican high grade metamorphism in cratonic rocks of southern Cameroon. Precambr Res 67: 321-347

Van Schmus W, Oliverra EP, Da Silva Filho AF, Toteu SF (2008) Proterozoic links between the Borborema Province, NE Brazil, and the Central African Fold Belt. In: Pankhurst RT, Trouw RAJ, Brito Neves BB, DE WIT MJ (eds) West Gondwana: Pre-Cenozoic Correlations Across the South Atlantic Region. Geological Society of London, Special Publications 294: 69-99

VAVRA G (1994) Systematics of internal zircon morphology in major Variscan granitoid types. Contrib Mineral Petrol 117: 331-344

Wandji P, Tchokona Seuwui D, BardintzefF JM, BelLON H, Platevoet B (2008) Rhyolites of the Mbépit Massif in the Cameroon Volcanic Line: an early extrusive volcanic episode of Eocene age. Mineral Petrol 94: 271-286

Wantim MN, Kervyn M, Ernest GGJ, Del Marmol M-A, SuH CE, JACOBS P (2013) Morpho-structure of the 1982 lava flow field at Mount Cameroon Volcano, West-Central Africa. Int J Geosci 4: 564-583
Wiedenbeck M, Alle P, Corfu F, Griffin WL, Meier M, Oberli F, Von Quadt A, Roddick JC, Spiegel W (1995) Three natural zircon standards for U-Th-Pb, Lu-Hf, trace element and REE analyses. Geostand News 1 19: 1-23

WiLliams IS (1998) U-Pb by ion microprobe. In: McKIBBen MA, Shanks WC, Ridley WI (eds) Applications of Microanalytical Techniques to Understanding Mineralizing Processes. Reviews in Economic Geology $7: 1-35$

Wilson CJN, CHARLIER BLA (2009) Rapid rates of magma generation at contemporaneous magma systems, Taupo Volcano, New Zealand: insights from U-Th model-age spectra in zircons. J Petrol 50: 875-905

Wilson CJN, CHARLIER BLA (2016) The life and times of silicic volcanic systems. Elements 12: 103-108

Wilson CJN, Hildreth W (1997) The Bishop Tuff: new insights from eruptive stratigraphy. J Geol 105: 407-440

Wotchoko P, Guimollaire ND, DJibril KNG, VohnyUi CM-L, Suh GC, Tangie BA, Dieudonne TS, Yannick S (2017) Petrogenesis of lava from Wainama West, Mount Oku (CVL): source characteristics and magma evolution. J Geosci Geom 5: 1-11

Youmen D, Schmincke H-U, Lissom J, Eetame J (2005) Geochronology data: evidence of different volcanic phases during the Miocene at Mount Bambouto (Cameroon line). Sci Technol Dév 11:49-57 